\title{
Trichodesmium spp. physiology and nutrient fluxes in the North Pacific subtropical gyre
}

\author{
Ricardo M. Letelier ${ }^{1, *}$, David M. Karl ${ }^{2}$ \\ ${ }^{1}$ College of Oceanic and Atmospheric Sciences, Oregon State University, Corvallis, Oregon 97331-5503, USA \\ ${ }^{2}$ School of Ocean and Earth Science and Technology, University of Hawaii, Honolulu, Hawaii 96822, USA
}

\begin{abstract}
The potential role of the diazotrophic cyanobacterium Trichodesmium spp. in nitrogen and phosphorus dynamics of the euphotic zone of the North Pacific subtropical gyre was investigated as one component of the Hawaii Ocean Time-series (HOT) program. Experiments were conducted with natural samples collected at Stn ALOHA $\left(22^{\circ} 45^{\prime} \mathrm{N}, 158^{\circ} \mathrm{W}\right)$ and with isolated cultures in laboratory. In both sets of experiments, we documented aerobic nitrogenase activity in Trichodesmium by acetylene $\left(\mathrm{C}_{2} \mathrm{H}_{2}\right)$ reduction to ethylene $\left(\mathrm{C}_{2} \mathrm{H}_{4}\right)$. Although average $\mathrm{C}_{2} \mathrm{H}_{4}$ evolution per unit chlorophyll a (chl a) was lower in naturally occurring single trichomes relative to colonies $\left[3.9\right.$ vs $12.5 \mathrm{nmol} \mathrm{C} \mathrm{H}_{4}(\mu \mathrm{g} \mathrm{chl} a)^{-1} \mathrm{~h}^{-1}$, respectively], the generally greater biomass of single trichomes in the North Pacific Ocean suggests that trichomes may be important in the oceanic $N$ cycle. Disrupted colonies display the lowest nitrogenase activities, but these activities increase with time in cultures. These observations and the relatively high dark oxygen consumption rates observed for Trichodesmium $\left[0.18 \mu \mathrm{mol} \mathrm{O} \mathrm{O}_{2}(\mu \mathrm{g} \mathrm{chl} \mathrm{a})^{-1} \mathrm{~h}^{-1}\right]$ suggest that, in nature, this cyanobacterium may be able to protect nitrogenase from oxygen inactivation, and that colony formation enhances, but is not prerequisite for, nitrogenase activity. Trichodesmium spp. collected from different depth strata at Stn ALOHA were also used to study variations in the C:N:P elemental composition of rising and sinking colonies. Although changes in elemental ratios were small, the relative $\mathrm{C}: \mathrm{N}$ increase in all sinking colonies and the $\mathrm{N}: \mathrm{P}$ decrease in rising colonies, sampled at approximately $100 \mathrm{~m}$ depth, is consistent with the model of Trichodesmium storage of carbohydrate in shallow waters $(<20 \mathrm{~m})$ and uptake of $P$ at depth. The active uptake of inorganic phosphorus measured in sinking colonies incubated in the dark combined with a change toward positive buoyancy in colonies during the incubation supports the hypothesis that vertical migrations of Trichodesmium may represent an upward transport of $\mathrm{P}$ into the euphotic zone and a potential decoupling of $\mathrm{N}$ and $\mathrm{P}$ nutrient cycles. However, these results do not explain the large concentration of non-migratory single trichomes observed in the upper water column of Stn ALOHA, unless colony versus free trichome morphology is a transient condition that is under cellular control.
\end{abstract}

KEY WORDS: Nitrogen fixation - Trichodesmium - Nutrients · North Pacific

\section{INTRODUCTION}

The high rates of photoautotrophic productivity in the euphotic zone of the North Pacific subtropical gyre appear to be inconsistent with the relatively low rates of inorganic nutrient input from beneath the permanent thermocline (King 1986, Lewis et al. 1986, Platt et al. 1989). A significant increase in measured primary productivity during years when the frequency of deep mixing events decreases (Karl et al. 1995, Letelier et al.

•E-mail: letelier@oce.orst.edu
1996) further exacerbates this condition and demands a closer examination of our basic paradigms of primary production and controls of nutrient fluxes in this oligotrophic ecosystem.

In recent years attention has been focused on other potential sources of inorganic nutrients including atmospheric depositions (Donaghay et al. 1991, Duce et al. 1991), stochastic storm-induced mixing (DiTullio \& Laws 1991), dinitrogen fixation (Capone \& Carpenter 1982, Karl et al. 1992) and vertical migrations of plant or animal communities (Villareal et al. 1993). In this context, the cyanobacterium Trichodesmium spp. has several characteristics relevant to the study of nutrient 
cycling in subtropical pelagic ecosystems. Two of these characteristics, directly related to the input of nutrients into the euphotic zone, are: (1) the faculty of dinitrogen fixation (Goering et al. 1966, Carpenter 1973, 1983, Wada \& Hattori 1991) and (2) the capacity of regulating cell density to effect a migration between the sea surface and the nutricline (Walsby 1978, 1992, Ganf \& Oliver 1982).

Although nitrogenase activity in Trichodesmium is well documented, the quantitative importance of $\mathrm{N}_{2}$ as a source of new nitrogen for the marine pelagic biota is uncertain (Carpenter \& Capone 1983, Codispoti 1989 and references therein, Carpenter \& Romans 1991). Dinitrogen fixation should represent an important fraction of new production in these regions unless growth is limited by nutrients other than nitrogen, as proposed by Martin \& Fitzwater (1988), or nitrogenase activity is inhibited by physical or chemical conditions in the environment (Doremus 1982, Reuter 1982, 1988, Howarth \& Cole 1985, Paerl \& Prufert 1987, Marino et al. 1990).

With the exception of the experiments conducted by Saino \& Hattori (1980), measurements of nitrogenase activity in Trichodesmium have been carried out preferentially in samples that selected for the colonial morphology (Dugdale et al. 1964, Mague et al. 1974, 1977. Carpenter \& McCarthy 1975, Carpenter \& Price 1977. McCarthy \& Carpenter 1979, Carpenter et al. 1987, Scranton et al. 1987). The strong bias toward the ecological study of colonies, rather than the native population containing both colonies and free filaments (trichomes), is probably due to the unsupported hypothesis that $\mathrm{N}_{2}$ fixation by Trichodesmium in nature is restricted to micro-aerophilic and anaerobic environments found in the center of colonies (Taylor et al. 1973, Carpenter \& Price 1976, Bryceson \& Fay 1981, Paerl \& Bland 1982, Carpenter 1983, Paerl \& Bebout 1988, Paerl et al. 1989). This bias may have resulted in an underestimation of the $\mathrm{N}_{2}$ fixation because, as reported in Marumo \& Asaoka (1974) and Letelier \& Karl (1996), most of Trichodesmium biomass at Stn ALOHA and in the North Pacific subtropical gyre is in the form of free filaments. Even though Saino \& Hattori (1980) reported significant $N_{2}$ fixation rates by naturally occuring single trichomes, the remaining evidence that single trichomes fix dinitrogen in natural environments has been only indirect (Saino \& Hattori 1982, Ohki \& Fujita 1988, Carpenter et al. 1990, Bergman et al. 1993). Furthermore, even if $\mathrm{N}_{2}$ fixation proved to be an important source of new nitrogen for the marine environment, the availability of other nutrients such as phosphorus and iron (Doremus 1982, Fogg 1982, Martin \& Fitzwater 1988) would limit the ecological benefits of an essentially unlimited nitrogen supply.
In 1992, Karl et al. proposed a phosphorus transport mechanism (P-Transport model) based on the capacity of Trichodesmium to control its buoyancy and migrate between light saturated-nutrient depleted (surface) waters and light limited-nutrient rich (deep) waters. In this model Trichodesmium accumulates energy in the form of heavy ballast polycarbohydrates under light saturated conditions near the surface and subsequently sinks into the nutricline ( 125 to $150 \mathrm{~m}$ ) where these carbohydrates are consumed to provide energy, in part, for the uptake and intracellular storage of phosphorus. Subsequent migration into surface waters, as a result of the consumption of the ballast, would provide the cells with an opportunity to grow at the expense of $\mathrm{N}_{2}$ and light, using these translocated P stores.

During the first few years of the Hawaii Ocean Timeseries (HOT) program we collected evidence suggesting that $\mathrm{N}_{2}$ fixation is an important source of new nitrogen to the biota at Stn ALOHA $\left(22^{\circ} 45^{\prime} \mathrm{N}, 158^{\circ} 00^{\prime} \mathrm{W}\right.$; Fig. 1), accounting for aproximately $50 \%$ of the exported $N$ production (Karl et al. 1995, 1997). Because over this period of time the only identified nitrogen fixers constantly present in our samples were Trichodesmium spp., we decided to investigate some basic physiological aspects of natural populations of these cyanobacteria at Stn ALOHA, in an attempt to understand their role in the nitrogen and phosphorus cycles of the North Pacific subtropical gyre. In the present paper, we report results of experiments addressing the importance of aerobic nitrogen fixation by Trichodesmium, including the potential contribution by naturally occurring single trichomes. We further assess the rates of oxygen consumption by these cyanobacteria as a mechanism to protect nitragenase from oxygen evolution and we compare the C:N:P elemental composition of positively and negatively buoyant colonies, as well as the rates of phosphorus uptake under dark conditions, in an attempt to understand the source of nutrients other than nitrogen supporting the Trichodesmium spp. populations at Stn ALOHA.

\section{METHODS}

Field $\mathrm{N}_{2}$ iixation assay. Nitrogenase activity of Trichodesmium colonies and single filaments collected in the euphotic zone at Stn ALOHA was estimated by $\mathrm{C}_{2} \mathrm{H}_{4}$ evolution during selected HOT cruises. Colonies and trichomes were isolated and transferred into filtered seawater as described in Letelier \& Karl (1996). Because of the low sensitivity of this assay, a large Trichodesmium biomass was required for each sample (>200 filaments per sample). Single trichomes used for these experiments were isolated from a large volume of seawater ( $>80 \mathrm{l}$ ) collected at a single predetermined 
Fig. 1. Map showing the position of Stn ALOHA relative to the Hawaiian Islands. Stn KAHE is a coastal station also occupied as part of the Hawaii Ocean Time-series program. Contour lines are water depth in meters

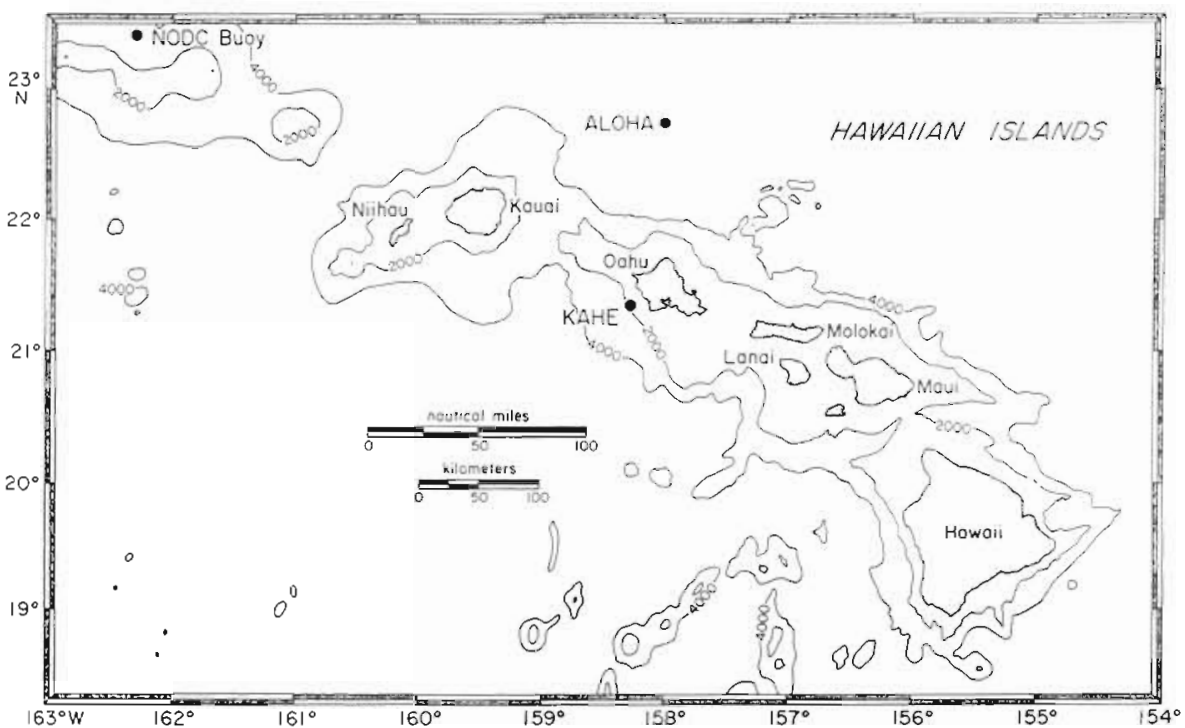

Colonies isolated from the original culture were also incubated under micro-aerophilic and aerobic environments following the same procedure. Nitrogenase activity was measured 3 times each day (07:00-08:00, 13:30-14:30 and 19:00-20:00 h), over a $4 \mathrm{~d}$ period. At each sampling period, $3 \mathrm{ml}$ aliquots were withdrawn from each flask and incubated for $1 \mathrm{~h}$ under modified natural light conditions in $13.5 \mathrm{ml}$ serum bottles filled with $2.0 \mathrm{ml} \mathrm{C}_{2} \mathrm{H}_{2}$ (approximately $15 \% \mathrm{v} / \mathrm{v}$ ). Transfers were made under a flow of $\mathrm{N}_{2}$ to maintain microaerophilic conditions, as required. The samples were placed into a temperature-controlled ( 24 to $26^{\circ} \mathrm{C}$ ), light incubator located in the roof of the Marine Science Building on the University of Hawaii campus. A combination of blue and neutral density filters in the incubators reduced the incident irradiance to $23.5 \%$ of ambient light. Termination of the incubation and measurement of $\mathrm{C}_{2} \mathrm{H}_{4}$ evolution were performed as described for the $\mathrm{N}_{2}$ fixation field assay. The cultures were monitored periodically for the formation of new colonies in single trichome suspensions by microscopic observation.

Oxygen evolution of colonies. Changes in the oxygen concentration in glass iodine flasks due to the metabolic activity of Trichodesmium colonies were quantified by potentiometric micro Winkler titration (Carpenter 1965) during April 17 and 18, 1992. Colonies were collected from the mixed-layer at Stn ALOHA and transferred into filtered seawater before inoculation.

Eight replicate samples of seawater collected at each of 4 depths $(5,25,45$ and $75 \mathrm{~m})$ were withdrawn into iodine flasks and capped until the addition of colonies. Of these 8 replicates, 4 randomly selected subsamples were inoculated with 5 colonies each. Immediately after the addition of colonies, the dissolved $\mathrm{O}_{2}$ content aerobic (air) conditions. 
of 1 sample with added Trichodesmium and 1 control bottle (filter seawater only) were fixed by the simultaneous addition of manganese chloride and alkaline iodide. The remaining samples were incubated ondeck at simulated in situ irradiance and temperature. One additional set of 8 replicates with seawater collected at $5 \mathrm{~m}$ depth was used to estimate oxygen changes in the dark for the Trichodesmium treatment only.

Comparison of elemental composition between positively and negatively buoyant colonies. Rising and sinking Trichodesmium colonies collected at approximately 5 and $100 \mathrm{~m}$ depth, as described by Letelier \& Karl (1996), were isolated during a $10 \mathrm{~min}$ separation period using 8 settling columns (SETCOL; Bienfang 1981). The segregated colonies were rinsed and transferred into $50 \mathrm{ml}$ of $0.2 \mu \mathrm{m}$ filtered seawater where they were mechanically disrupted to produce suspensions of single trichomes. From each suspension, $10 \mathrm{ml}$ aliquots were filtered onto combusted $25 \mathrm{~mm}$ GF/F Whatman filters and stored frozen for subsequent particulate carbon (PC) and particulate nitrogen (PN) analyses. Ten ml aliquots were also filtered though combusted and acid-washed $(\mathrm{HCl})$ $25 \mathrm{~mm} \mathrm{GF} / \mathrm{F}$ Whatman filters and stored frozen for subsequent particulate phosphorus (PP) analyses. PC and PN were measured using a Perkin-Elmer model 2400 CHN analyzer and PP was quantified spectrophotometrically after combustion $\left(450\right.$ to $500^{\circ} \mathrm{C}$ ) and acidification $\left(0.5 \mathrm{~N} \mathrm{HCl}\right.$ at $90^{\circ} \mathrm{C}$ for $\left.90 \mathrm{~min}\right)$ according to the method of Karl et al. (1996).

Dark phosphorus uptake. Phosphorus uptake by sinking Trichodesmium colonies incubated in filtered seawater was measured using ${ }^{32} \mathrm{P}$ as a tracer (in the form of $\mathrm{H}_{3}{ }^{32} \mathrm{PO}_{4}$; carrier free, ICN Radiochemicals). Five liters of water collected at $150 \mathrm{~m}$ depth at Stn ALOHA were sterile filtered through a $0.2 \mu \mathrm{m}$ Nalgene filter and stored in acid washed polycarbonate bottles. Subsamples of the filtered water were withdrawn for soluble reactive phosphorus (SRP) and total dissolved phosphorus (TDP) analyses. SRP concentration was estimated by the molybdenum blue reaction (Murphy \& Riley 1962). TDP was estimated using the same procedure after liberating the combined phosphorus by ultraviolet photolytic oxidation (Armstrong et al. 1966). Dissolved organic phosphorus (DOP) concentration was estimated as [TDP] - [SRP] which assumes that all soluble non-reactive $P$ is organic.

Sinking colonies, collected at approximately $5 \mathrm{~m}$ depth, were isolated using SETCOL columns and were rinsed before transferring them into polycarbonate incubation bottles containing filtered seawater. Three incubation bottles with Trichodesmium colonies and a negative control (filtered seawater without colonies) were prepared for this experiment. Each bottle was filled with $500 \mathrm{ml}$ of $150 \mathrm{~m}$ depth filtered seawater and 45 colonies were added to each of 3 bottles. Radiotracer ${ }^{32} \mathrm{P}$ was added to each bottle to yield a final activity of $2.8 \mathrm{MBq}^{32} \mathrm{P} \mathrm{I}^{-1}$. The initial specific activity was $15.5 \mathrm{MBq}$ ( $\mu$ mol SRP) $)^{-1}$ or $7.7 \mathrm{MBq}(\mu \mathrm{mol} \text { TDP })^{-1}$. All samples were kept in the dark and at simulated in situ temperature during the incubation.

Prior to the inoculation with ${ }^{32} \mathrm{P}, 5$ Trichodesmium colonies from each bottle were removed by Pasteur pipette to measure the initial chl a:PP ratio. These colonies were resuspended in $50 \mathrm{ml}$ filtered seawater and vortexed until only single trichomes were observed in order to obtain a homogeneous suspension of filaments. Twenty-five $\mathrm{ml}$ of each suspension was concentrated onto a combusted acid washed $25 \mathrm{~mm} \mathrm{GF} / \mathrm{F}$ filter and rinsed twice with $10 \mathrm{ml}$ filtered seawater prior to PP analyses. Chl a was extracted from the remaining $25 \mathrm{ml}$ by filtering the sample through a $25 \mathrm{~mm}$ GF/F Whatman filter and storing the sample in $100 \%$ acetone at $-20^{\circ} \mathrm{C}$. The extracted chl a concentrations were measured by fluorometry.

Samples, consisting of either 5 colonies per bottle and $5 \mathrm{ml}$ of the negative control (filter seawater without Trichodesmium), were withdrawn approximately every $6 \mathrm{~h}$ during the first $24 \mathrm{~h}$. The colonies were rinsed twice, resuspended in $50 \mathrm{ml}$ filtered seawater and vortexed until obtaining an homogeneous filament suspension. A set of samples was collected immediately after the addition of ${ }^{32} \mathrm{P}(t=0 \mathrm{~h})$ and 1 final set was collected after a $48 \mathrm{~h}$ incubation period. Twenty-five $\mathrm{ml}$ of suspension was used for chl a determination and the remaining $25 \mathrm{ml}$ was filtered through a $25 \mathrm{~mm} \mathrm{GF} / \mathrm{F}$ Whatman filter, rinsed twice with filtered seawater and the filters stored at $4^{\circ} \mathrm{C}$ in polyethylene scintillation vials for determination of inorganic phosphorus uptake. Specific activity in each incubation bottle was estimated from triplicate $1 \mathrm{ml}$ samples withdrawn at the beginning of the incubation. In addition, triplicate $1 \mathrm{ml}$ samples were withdrawn at each experimental time-point to assess the remaining ${ }^{32} \mathrm{P}$ in solution for mass balance determination. Radioactivity was measured as soon as we returned to our shore based laboratories by the Cerenkov technique (Kamp \& Blanchard 1971) using a Packard Tri-Carb scintillation counter. Counting efficiency was $43 \%$

\section{RESULTS}

\section{Nitrogen fixation}

All Trichodesmium samples collected at Stn ALOHA had measurable nitrogenase activity (Table 1, Fig. 2). The activity appeared to display limited photoinhibi- 
Table 1. Comparison of the aerobic evolution of ethylene $\left(\mathrm{C}_{2} \mathrm{H}_{4}\right)$ by single trichomes, intact colonies, and disrupted colonies for a sample collected at Stn ALOHA. Values are means ( \pm 1 standard deviation) following a $1 \mathrm{~h}$ incubation

\begin{tabular}{|cccc|}
\hline $\begin{array}{c}\text { Collection } \\
\text { depth }(\mathrm{m})\end{array}$ & \multicolumn{3}{c|}{$\begin{array}{c}\text { Nitrogenase activity } \\
\text { [nmol C }\end{array}$} \\
& $\begin{array}{c}\text { Single } \\
\text { trichomes }\end{array}$ & $\begin{array}{c}\text { Intact } \\
\text { colonies }\end{array}$ & $\begin{array}{c}\text { Disrupted } \\
\text { colonies }\end{array}$ \\
\hline 5 & $2.3(0.4)$ & $7.6(1.1)$ & $0.3(0.2)$ \\
25 & $3.6(0.9)$ & $12.3(1.6)$ & $0.7(0.3)$ \\
45 & $3.1(0.7)$ & $11.7(2.6)$ & $0.5(0.4)$ \\
75 & $0.3(0.3)$ & $3.1(1.8)$ & $0.1(0.2)$ \\
\hline
\end{tabular}

tion when samples were incubated at $45 \%$ surface irradiance light levels (5 $\mathrm{m}$ depth). Although detectable, the $\mathrm{C}_{2} \mathrm{H}_{4}$ evolution by disrupted colonies incubated under aerobic conditions was inhibited by as much as $98 \%$ relative to the evolution measured in intact colonies. However, naturally occurring single trichomes incubated under aerobic conditions produced $\mathrm{C}_{2} \mathrm{H}_{4}$ at rates up to $30 \%$ of those total measured in intact colonies. Chl a-specific $\mathrm{C}_{2} \mathrm{H}_{4}$ production rates were not significantly different between 25 and $45 \mathrm{~m}$ depth $\left[3.6 \pm 0.9\right.$ and $3.1 \pm 0.7 \mathrm{nmol} \mathrm{C}_{2} \mathrm{H}_{4}(\mu \mathrm{g} \mathrm{chl} \mathrm{a})^{-1} \mathrm{~h}^{-1}$ for naturally occurring single trichomes and $12.3 \pm 1.7$ and $11.7 \pm 2.6 \mathrm{nmol} \mathrm{C}_{2} \mathrm{H}_{4}(\mu \mathrm{g} \mathrm{chl} \mathrm{a})^{-1} \mathrm{~h}^{-1}$ for colonies: $p>0.1$, suggesting that nitrogenase activity is still light saturated at $45 \mathrm{~m}$ at the time this experiment took place $(10: 15$ to $12: 15 \mathrm{~h})$.

Nitrogenase activity measured in Trichodesmium cultures displayed a strong diel cycle with highest values [approximately $50 \mathrm{nmol} \mathrm{C}_{2} \mathrm{H}_{4}(\mu \mathrm{g} \mathrm{chl} \mathrm{a})^{-1} \mathrm{~h}^{-1}$ ] measured at the time of highest solar irradiance (Table 2 , Fig 3). Although evolution of $\mathrm{C}_{2} \mathrm{H}_{4}$ in all samples containing Trichodesmium was higher than the controls, the increase was not significant $(p>0.1)$ in aerobically grown single trichomes during the first $40 \mathrm{~h}$ after disruption. Nevertheless, after this initial lag period, nitrogenase activity in this treatment increased to values of about $35 \%$ of the nitrogenase activity measured in colonies grown under aerobic conditions (Fig. 3B).

Colonies kept under aerobic conditions yielded consistently lower nitrogenase activity than colonies kept in subaerobic conditions. However, the relatively lower activity under aerobic conditions was on average only $24 \%$ with larger values during early morning and late evening and lower values at local apparent noon (Table 2).

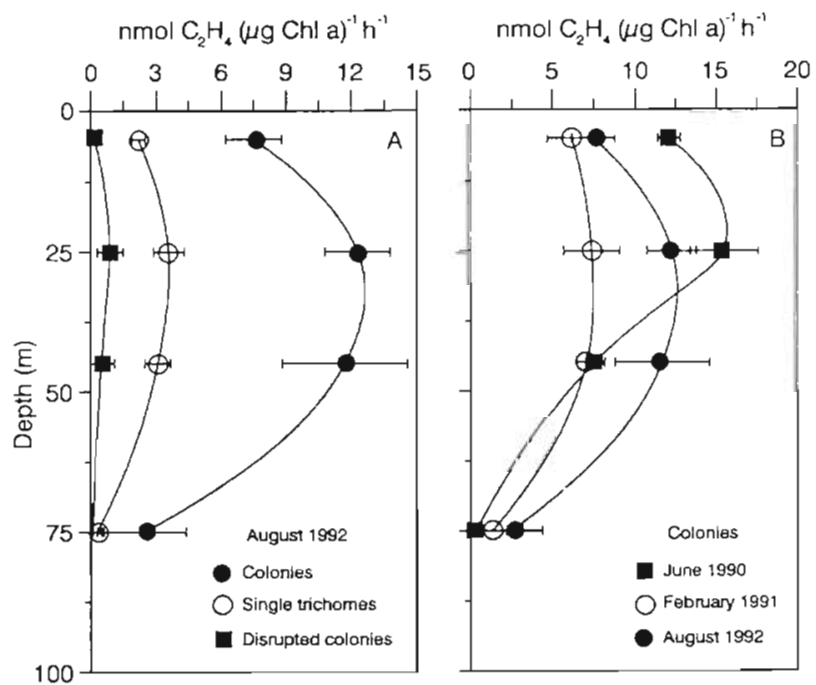

Fig. 2. (A) Depth profile of aerobic acetylene reduction $\left(\mathrm{C}_{2} \mathrm{H}_{4}\right.$ evolution) by Trichodesmium colonies, disrupted colonies, and naturally occurring single trichomes collected at Stn ALOHA and incubated under simulated in situ irradiance and temperature. (B) Depth profile of aerobic acetylene reduction $\left(\mathrm{C}_{2} \mathrm{H}_{4}\right.$ evolution) by colonies collected during different cruises. Error bars indicate \pm 1 standard deviation

\section{Oxygen evolution}

Trichodesmium colonies display an unusually shallow compensation depth (Fig. 4A) relative to other pelagic photoautotrophs. Although net oxygen evolu-

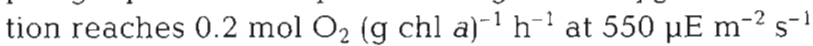
$(\sim 10 \mathrm{~m}$; Fig. $4 \mathrm{~B})$, at $25 \mathrm{~m}$ depth it is not significantly different from zero $(p>0.1)$. At $75 \mathrm{~m}$ the net oxygen evolution in the light is not statistically different from the oxygen consumption measured in samples incubated

Table 2. Daily variations in nitrogenase activity measured as $\mathrm{nmol} \mathrm{C}_{2} \mathrm{H}_{4}$ ( $\mathrm{kg}$ chl $a)^{-1} \mathrm{~h}^{-1}$ in Trichodesmium cultures incubated under aerobic and microaerophilic conditions. Values are means ( \pm 1 standard deviation) following a $1 \mathrm{~h}$ incubation

\begin{tabular}{|c|c|c|c|c|}
\hline \multirow{2}{*}{$\begin{array}{l}\text { Date-time } \\
\text { (mo/d/yr-h) }\end{array}$} & \multicolumn{2}{|c|}{ Colonies } & \multicolumn{2}{|c|}{ Filaments } \\
\hline & Aerobic & $\begin{array}{l}\text { Micro- } \\
\text { aerophilic }\end{array}$ & Aerobic & $\begin{array}{c}\text { Micro- } \\
\text { aerophilic }\end{array}$ \\
\hline $11 / 12 / 90-07: 30$ & $3.3(2.1)$ & $4.3(2.1)$ & $0.9(1.1)$ & $2.0(0.4)$ \\
\hline $11 / 12 / 90-14: 00$ & $26.9(1.3)$ & $33.2(1.4)$ & $1.6(1.7)$ & $26.6(1.2)$ \\
\hline $11 / 12 / 90-19: 30$ & $4.9(1.3)$ & $9.8(1.5)$ & $1.2(0.8)$ & $7.4(1.9)$ \\
\hline $11 / 13 / 90-07: 30$ & $10.2(1.1)$ & $15.6(1.0)$ & $1.1(0.8)$ & $9.7(0.7)$ \\
\hline $11 / 13 / 90-14: 00$ & $34.5(1.0)$ & $42.8(0.8)$ & $8.5(0.5)$ & $32.8(1.6)$ \\
\hline $11 / 13 / 90-19: 30$ & $9.4(1.6)$ & $11.6(1.1)$ & $2.7(0.6)$ & $8.0(0.9)$ \\
\hline $11 / 14 / 90-07: 30$ & $13.1(3.7)$ & $17.6(0.7)$ & $4.1(3.6)$ & $11.4(0.8)$ \\
\hline $11 / 14 / 90-14: 00$ & $42.5(1.8)$ & $50.0(2.7)$ & $15.4(0.7)$ & $35.7(0.7)$ \\
\hline $11 / 14 / 90-19: 30$ & $8.6(0.5)$ & $13.4(2.4)$ & $3.0(0.4)$ & $9.6(0.5)$ \\
\hline $11 / 15 / 90-07: 30$ & $11.7(1.2)$ & $14.7(0.7)$ & $4.3(1.3)$ & $9.3(0.4)$ \\
\hline $11 / 15 / 90-15: 00$ & $45.5(1.4)$ & $47.3(1.2)$ & $16.3(1.3)$ & $33.7(1.4)$ \\
\hline
\end{tabular}



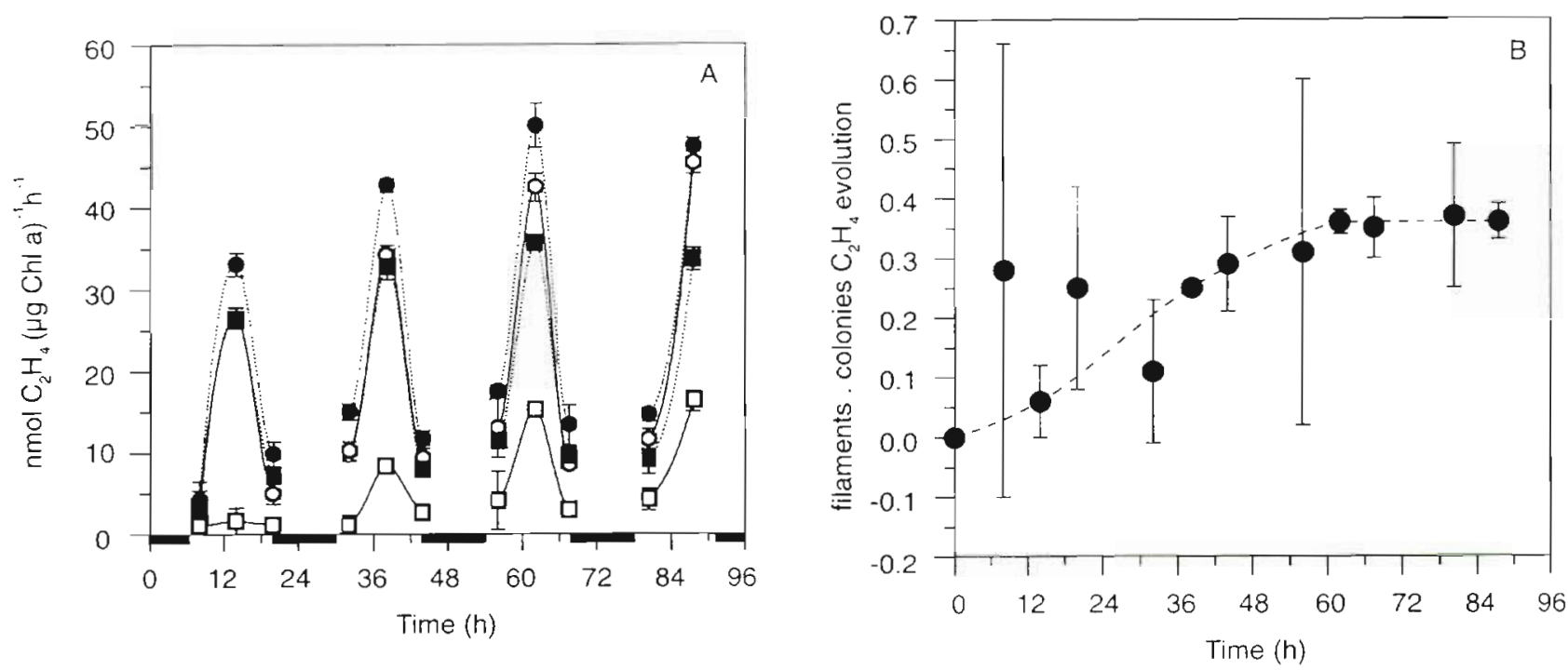

Fig. 3. (A) Temporal changes in acetylene reduction $\left(\mathrm{C}_{2} \mathrm{H}_{4}\right.$ evolution) measured in disrupted and intact Trichodesmium colonies grown in culture (solid symbols = micro-aerobic; open symbols = aerobic; squares $=$ disrupted colonies; circles $=$ intact colonies) (B) Temporal aerobic trend of acetylene reduction $\left(\mathrm{C}_{2} \mathrm{H}_{4}\right.$ evolution) by disrupted Trichodesmium colonies under aerobic conditions expressed as the fraction of acetylene reduction measured in intact colonies. Error bars indicate \pm 1 standard deviation
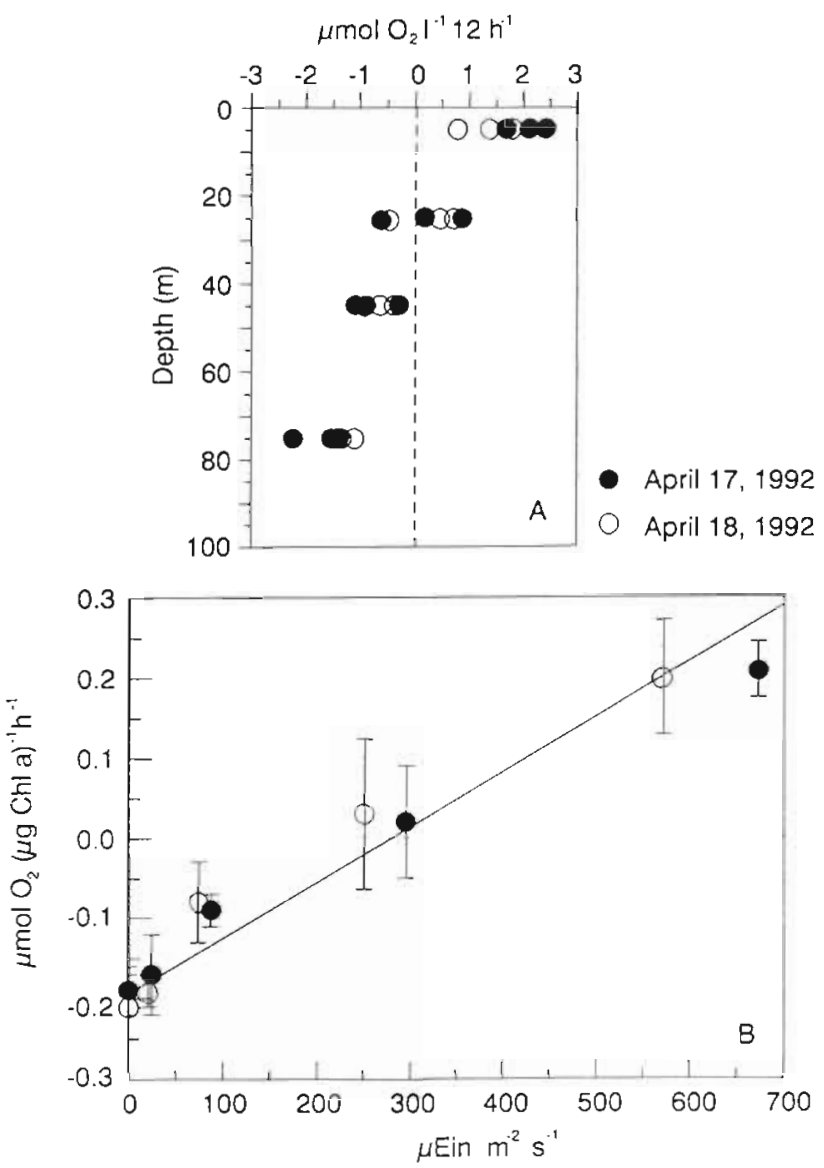

Fig. 4. Net oxygen changes during shipboard incubation of Trichodesmium colonies collected on 2 consecutive days at Stn ALOHA. (A) Depth profile, (B) oxygen plotted against. irradiance. Error bars indicate \pm 1 standard deviation

in the dark ( $p>0.1)$, suggesting that photosynthetic carbon assimilation at this depth is negligible. Over the light range of our incubations net oxygen evolution may be described by a geometric mean (model II) linear function of the photon flux $\left[y=-0.18+6.7 \times 10^{-4} \times\right.$

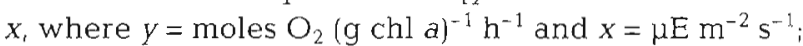
$\mathrm{R}^{2}=0.873, \mathrm{n}=29$.

\section{Elemental composition}

The C:N:P elemental ratios obtained from positively and negatively buoyant colonies collected at different depth strata suggest only subtle changes in the elemental composition of Trichodesmium (Table 3). Sinking colonies have, on average, a PC:PN ratio higher than the Redfield stoichiometry (Redfield et al. 1963), while rising colonies are, on average, below this ratio. The lowest average concentration of PC per unit PN is found in rising colonies collected at $100 \mathrm{~m}$ depth, suggesting either a net consumption of cellular carbon per unit nitrogen or active assimilation of nitrogen relative to carbon at depth, or both.

The PP content of Trichodesmium colonies is consistently lower, with respect to PC and PN, than Redfield stoichiometry of $106 \mathrm{C}: 16 \mathrm{~N} \cdot 1 \mathrm{P}$ (Table 3). The lowest mean PN:PP measured $(34.2 \pm 2.8)$ was found in rising colonies collected at $100 \mathrm{~m}$ depth. This value is 2.2 times greater than the Redfield ratio of $16: 1$ and about $30 \%$ lower than that measured for colonies sampled at $5 \mathrm{~m}$ depth. 
Table 3. Comparison of elemental ratios (particulate carbon:particulate nitrogen, PC:PN, and particulate nitrogen:particulate phosphorus, $\mathrm{PN}: \mathrm{PP}$ ) in sinking and rising colonies collected at surface $(5 \mathrm{~m})$ and depth $(100 \mathrm{~m})$ at Stn ALOHA. Values are means ( \pm 1 standard deviation)

\begin{tabular}{|lcccc|}
\hline \multirow{2}{*}{ Buoyancy } & \multicolumn{2}{c}{ PC:PN } & \multicolumn{2}{c|}{ PN:PP } \\
& $5 \mathrm{~m}$ & $100 \mathrm{~m}$ & $5 \mathrm{~m}$ & $100 \mathrm{~m}$ \\
\hline Sinking & $7.32(0.36)$ & $6.61(0.27)$ & $42.76(1.71)$ & $44.80(1.12)$ \\
Rising & $6.32(0.32)$ & $5.88(0.34)$ & $43.75(1.64)$ & $34.19(2.83)$ \\
\hline
\end{tabular}

observation indicates that nitrogenase activity is not protected from photosynthetic $\mathrm{O}_{2}$ evolution as a result of the absence of photosystems II in the central region of the colony, as initially proposed by Carpenter \& Price (1976). Furthermore, nitrogenase activity in Trichodesmium appears to be strongly dependent on light (Fig. 3A; Saino \& Hattori 1978, Ohki \& Fujita 1988), suggesting that there is no temporal separation between photosynthesis and nitrogen fixation.

Field and laboratory data obtained during our study at Stn ALOHA support the results of Saino \& Hattori (1980) and reinforce the notion that, under ambient oxygen levels, $\mathrm{N}_{2}$ fixation is reduced but not completely suppressed. These data also suggest that Triduring the first 12 to $24 \mathrm{~h}$ of incubation (Fig. 5). Based on the SRP concentration in the incubation bottles at the beginning of the incubation period $(0.18 \mu \mathrm{M})$ and the phosphorus specific activity $[15.5 \mathrm{MBq}$ (umol $\mathrm{SRP})^{-1}$ ] it is possible to calculate the absolute inorganic phosphorus uptake by Trichodesmium in this experiment. During the first $13 \mathrm{~h}$, the uptake rate per unit chl a appears to be constant [approximately $6 \times 10^{-2} \mathrm{ng}$ $\mathrm{P}$ (ng chl $a)^{-1} \mathrm{~h}^{-1}$ ]. The largest accumulation of ${ }^{32} \mathrm{PO}_{4}{ }^{3-}$ [1.29 ng P (ng chl a) ${ }^{-1}$ ] was measured in the $24 \mathrm{~h}$ time point samples. Nevertheless, it should be noted that values measured at 13,19 , and $48 \mathrm{~h}$ after the beginning of the incubation are not statistically different $(p<0.05)$.

The concentration of $\mathrm{chl} a$ in colonies does not vary significantly over time (Fig. 5A), suggesting that dark photoadaptation is negligible in colonies during the incubation. Using the PP:chl a ratio (2.2:1 w:w) measured at the beginning of this experiment it is possible to normalize phosphorus uptake to initial phosphorus content. Based on this calculation, we find that sinking Trichodesmium colonies were able to assimilate the equivalent of 35 to $57 \%$ of their phosphorus content from inorganic phosphorus over the first $12 \mathrm{~h}$ of dark incubation during HOT-49 (September 1993; Fig. 5).

\section{DISCUSSION}

In 1980 and 1982, Saino \& Hattori presented strong evidence that Trichodesmium is able to fix nitrogen under aerobic conditions. However, until recently nitrogenase activity was still thought to be restricted to low oxygen environments within Trichodesmium colonies (Paerl et al. 1989). A re-evaluation of Trichodesmium nitrogenase activity under aerobic conditions has been conducted recently (Capone et al. 1990 , Carpenter et al. 1990, Bergman et al. 1993, PrufertBebout et al. 1993). As part of this reassessment, Carpenter et al. (1990) found an even distribution of photosystems I and II in the colonial trichomes. This

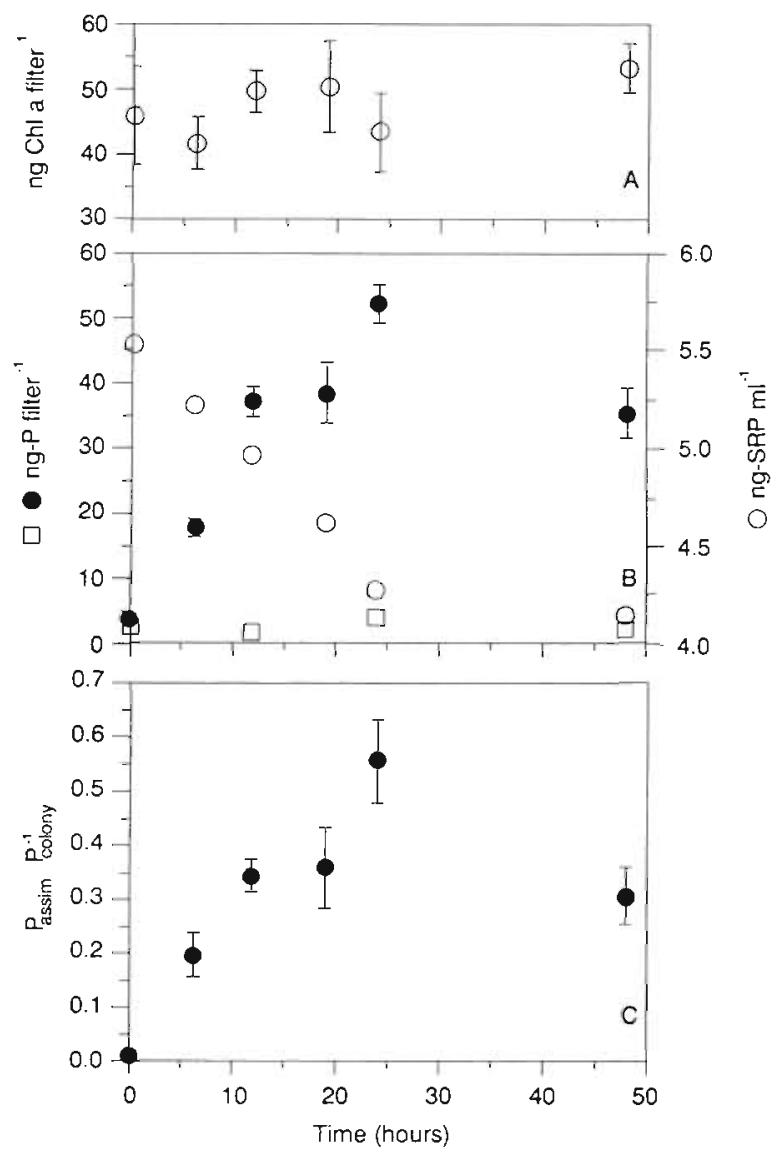

Fig. 5. Dark phosphorus uptake by Trichodesmium sinking colonies measured by ${ }^{32} \mathrm{PO}_{4}$ assimilation. (A) Chlorophyll a concentration per sample filtered. (B) Time course of phosphorus assimilation based on soluble reactive phosphorus (SRP) concentration ( : phosphorus uptake in 5 colonies; $\square$ : phosphorus uptake by particulate matter other than colonies in $5 \mathrm{ml}$ samples; O: SRP concentration in the incubation medium). (C) Inorganic phosphorus assimilation normalized to the initial phosphorus content in Trichodesmium colonies. Error bars indicate \pm 1 standard deviation 
chodesmium possesses an intracellular oxygen scavenging mechanism that is capable of protecting nitrogenase activity from $\mathrm{O}_{2}$ inactivation. When single trichomes obtained from the disruption of colonies grown in culture without combined nitrogen were incubated under aerobic conditions, there was a lag period of approximately $40 \mathrm{~h}$ before nitrogenase activity was significantly different than seawater controls (Fig. 3A). This lag period could not be attributed to the handling of the samples during the disruption process because single trichomes obtained in the same manner but incubated under micro-aerophilic conditions displayed nitrogenase activity close to the activity measured in colonies. Also, field sample results indicate that naturally occurring free trichomes incubated under aerobic conditions have higher nitrogenase activity than filaments obtained from colonies by mechanical disruption (Fig. 2A). Furthermore, Trichodesmium colonies at Stn ALOHA display high consumption of $\mathrm{O}_{2}$ under light conditions (Fig. 4B). This phenomenon has also been observed by Kana (1992) who attributed the high $\mathrm{O}_{2}$ consumption to the Mehler reaction (production of $\mathrm{O}_{2}{ }^{-}$by photosystem I followed by the conversion of $\mathrm{O}_{2}^{-}$ into $\mathrm{H}_{2} \mathrm{O}_{2}$ by a superoxide dismutase) and to a high basal respiration rate.

Cunningham \& Capone (1992) have reported the presence of a Fe superoxide dismutase in Trichodesmium, and Bergman et al. (1993) observed a strong correlation between the expression of nitrogenase and an $a_{3}$-type cytochrome oxidase in Trichodesmium thiebautii cells. The lag period measured for $\mathrm{N}_{2}$ fixation after the disruption of colonies grown in culture suggests that these biochemical processes are not always present at a level sufficient to protect nitrogenase activity from oxygen evolution in our Trichodesmium cultures. However, the existence of this lag period is absent in the Saino \& Hattori (1982) report, as well as in the results of field experiments with disrupted colonies developed during this study. Colonies collected from natural populations that had been disrupted and incubated under aerobic conditions display highly reduced but still detectable nitrogenase activity (Fig. 2; Saino \& Hattori 1982).

The light intensity used for the laboratory culture experiments (15 to $\left.30 \mu \mathrm{E} \mathrm{m}^{-2} \mathrm{~s}^{-1}\right)$ may help explain this discrepancy. Under low irradiance, respiration rates must decrease in order to sustain net growth rate. Because $\mathrm{N}_{2}$ fixation has a higher demand for adenosine triphosphate (ATP) relative to reduced nicotinamide adenine dinucleotide phosphate (NADPH), the Mehler reaction may play an important role, not only by removing oxygen, but also by controlling the supply of ATP for nitrogenase activity (Kana 1992). Hence, when grown under dim light, it may be to the advantage of Trichodesmium to couple the removal of oxy- gen with light processes (Mehler activity) rather than to maintain an elevated respiration rate.

A sudden increase of oxygen and light upon the disruption of colonies may also change the balance of enzymatic processes controlling the intracellular oxygen. Although this is also true for colonies collected from natural environments, the average radiant flux penetrating down to $45 \mathrm{~m}$ during a summer day at

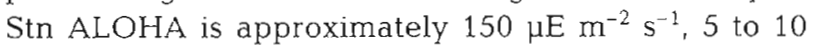
times the irradiance of cultures studies (at $5 \mathrm{~m}$ depth the light is 50 times higher). Hence, it is possible that colonies collected at Stn ALOHA, having a higher respiratory oxygen uptake relative to colonies grown in culture, are able to control more effectively the increase of intracellular oxygen tension. Furthermore, Trichodesmium grown under dim light would not be expected to accumulate polycarbohydrates to the extent that they do when incubated under high light (Li et al. 1980). This reserve of reduced carbon may be important for respiration and the removal of oxygen.

It is interesting to note that the short term (1 to $2 \mathrm{~h}$ ) nitrogenase activity measured at Stn ALOHA appears to be partially inhibited when samples are incubated at $5 \mathrm{~m}$ depth light irradiance (Fig. 2). This observation, combined with results from the net oxygen evolution by Trichodesmium colonies (Fig, 4), suggests that the optimum light depth for this cyanobacterium to grow and fix $\mathrm{N}_{2}$ is probably close to $25 \mathrm{~m}$ depth. This is also the depth at which a Trichodesmium biomass maximum is measured under stratified water column conditions (mixed layer $<25 \mathrm{~m}$ ) and non-bloom conditions at Stn ALOHA (Letelier \& Karl 1996).

Although sinking and rising colonies isolated from different depth strata at Stn ALOHA display only minor changes in their bulk $\mathrm{C}: \mathrm{N}: \mathrm{P}$ composition (most of them are not statistically different at $\alpha=0.05$ ), the changes follow a consistent pattern (Table 3 ) and support the phosphorus-transport model postulated by Karl et al. (1992; see also Kromkamp \& Mur 1984, Fogg 1987). Throughout the water column, Trichodesmium has elevated $C: P$ and $N$ :P ratios, relative to the classic Redfield ratio, and this may be a specific cellular adaptation for growth in low phophorus environments. This P-sparing effect has been reported previously, but the biochemical basis of the effect is not known.

Sinking colonies are enriched in carbon and depleted in phosphorus relative to nitrogen when compared to rising colonies. The increase in carbon may be explained by a preferential carbon assimilation into polycarbohydrates by Trichodesmium cells (Roman et al. 1994) as observed by Li et al. (1980) in samples collected at shallow depths and incubated under high irradiance $\left(100\right.$ to $\left.1500 \mu \mathrm{E} \mathrm{m}^{-2} \mathrm{~s}^{-1}\right)$. This relative increase in carbon is also in agreement with the hypothesis that Trichodesmium cell density is regulated by 
the synthesis and degradation of polycarbohydrate reserves (Villareal \& Carpenter 1990). Nevertheless, we should be careful with the interpretation of cellular $\mathrm{C}: \mathrm{N}$ ratios, and how it relates to buoyancy. During an August 1989 Trichodesmium bloom at Stn ALOHA the C:N ratio of floating colonies was 7.1:1 (mol:mol). A similar ratio (7:1) was measured by Lewis et al. (1988) during a summer bloom in the North Atlantic. The mean ratio of sinking colonies collected from $5 \mathrm{~m}$ depth at Stn ALOHA under non-bloom conditions is only $6.9: 1( \pm 0.3: 1)$.

The exact reason why cyanobacteria lose the capacity to control the cellular density under bloom conditions is not known. In freshwater systems the collapse of gas vacuoles due to a decrease in the availability of inorganic carbon has been shown to be an important factor (Klemer et al. 1982). This is probably not the case for Trichodesmium because of the high critical pressure for the collapse of its gas vesicules (Walsby 1978) and the high, non-limiting, concentration of dissolved inorganic carbon in seawater.

An alternative hypothesis states that cell metabolism and the physiological state of an organism is regulated by the source and availability of nutrients (Konopka 1984). Under non-bloom conditions Trichodesmium growth in shallow waters is probably limited by the availability of elements other than carbon, hydrogen; oxygen and nitrogen. It is also possible that limitation by phosphorus (or other limiting nutrient) increases the allocation of carbon assimilated into high density carboxysomes. Trichodesmium colonies appear to have high degradation rates during bloom events, increasing the availability of nutrients where large ocean surface accumulations are found (Devassy et al. 1978, Fogg et al. 1987). If the growth rate of Trichodesmium is balanced by the degradation rate, nutrient limitation will not take place and probably less carbon assimilation will go into carbohydrate ballast. However, inorganic carbon uptake will have to remain large relative to nitrogen uptake in order to produce $\mathrm{C}: \mathrm{N}$ ratios equal to $7: 1$ or greater. Under this hypothesized growth condition, cells close to the surface will not sink (they will only grow, degrade or be grazed) and the net increase in Trichodesmium biomass will be mainly the result of colonies growing and transporting nutrients to the surface by active vertical migration.

The evidence for an active uptake of inorganic phosphorus by Trichodesmium in the dark is supported by the variation of $\mathrm{N}: \mathrm{P}$ between sinking and rising colonies collected at depth (Table 3), as well as by the results from the dark incubations of sinking colonies in nutrient-rich waters (Fig. 5). If we assume no absolute changes in the Trichodesmium nitrogen content between sinking and rising colonies, then the decrease in the $N$ :P ratio from $45: 1$ to $34: 1$ reflects an increase in cellular phosphorus content of $32 \%$. This result is similar to the increase calculated from the inorganic phosphorus uptake during dark incubations. Nevertheless, we should be aware that the dark incubation results may be biased for several reasons. Sinking colonies collected close to the surface at mid morning were suddenly transferred into a medium rich in $\mathrm{HPO}_{4}{ }^{2-}$ and kept in the dark for $48 \mathrm{~h}$. This procedure may have produced an overestimation of the in situ phosphorus uptake because, in nature, colonies must expend cellular energy to migrate down to the nutricline. Furthermore, as soon as the cells become positively buoyant colonies will start migrating away from the nutricline.

During our experiment approximately $15 \%$ of the colonies were observed to be positively buoyant after a $6 \mathrm{~h}$ incubation and $100 \%$ after $18 \mathrm{~h}$. Because phosphorus uptake is an active process (it requires energy) a potentially high cellular energy reserve at the beginning of the experiment (colonies did not respire carbohydrate reserves during their migration toward the nutricline) could produce an overestimation of the natural phosphorus uptake. This effect is probably further aggravated by maintaining the colonies in an artificially high inorganic phosphorus environment once buoyancy has changed. Nevertheless, the results of the ${ }^{32} \mathrm{P}$ uptake experiments, although not conclusive with respect to the maximum absolute uptake of inorganic phosphorus by Trichodesmium, suggest that active uptake only occurs during the first 12 to $24 \mathrm{~h}$. Because most of the colonies were still negative or neutrally buoyant after $6 \mathrm{~h}$ incubation, we believe that the artificial confinement of Trichodesmium does not contribute significantly to an overestimation of the absolute uptake of inorganic phosphorus when $12 \mathrm{~h}$ incubation results are used.

On the other hand our experiment may have underestimated the total assimilation of phosphorus because Trichodesmium displays high alkaline phosphatase activity (Yentsch \& Yentsch 1972, McCarthy \& Carpenter 1979, Elardo et al. 1994). On the date of the ${ }^{32} \mathrm{PO}_{4}$ uptake experiment the concentration of dissolved organic phosphorus (DOP) in the first $100 \mathrm{~m}$ depth at Stn ALOHA was consistently above $150 \mathrm{nM}$, a value that was 5 to 6 times higher than the concentration of inorganic phosphorus measured in the same depth range (Fig. 6; also see Karl \& Tien 1997). If we assume that Trichodesmium uses both pools at the same rate then the amount of phosphorus assimilated doubles. Our experiment did not discriminate between SRP and DOP uptake and, because DOP may be an equally important source of phosphorous, the total uptake measured by ${ }^{32} \mathrm{PO}_{4}$ incorporation using SRP concentrations to calculate $\mathrm{P}$-specific activity gives only a conservative estimate of the total phosphorus uptake. Nevertheless, if the Trichodesmium P-transport model 


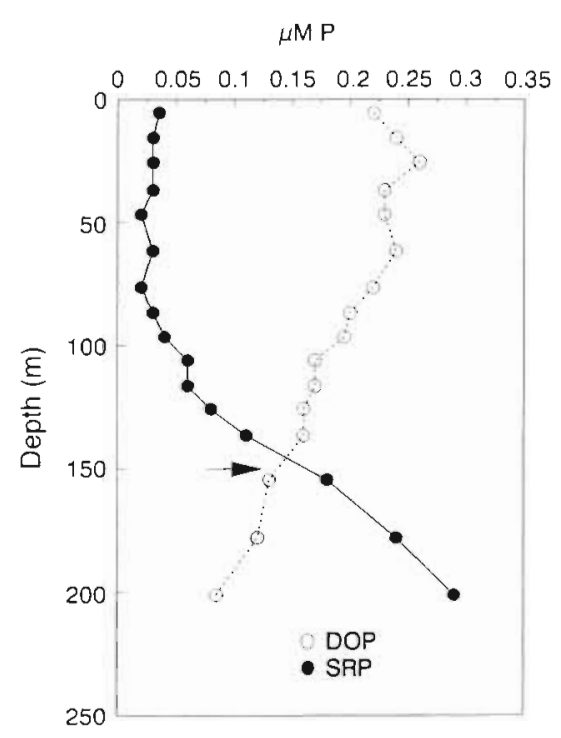

Fig. 6. Depth distribution (0 to $200 \mathrm{~m}$ ) of dissolved organic phosphorus (DOP) and soluble reactive phosphorus (SRP) at Stn ALOHA during September 1993

represents a source of phosphorus and other nutrients to the upper euphotic zone, Trichodesmium vertical migrations must be regarded as a sink of energy and a source of inorganic nutrients for a stratified euphotic zone as suggested by our results. Uptake of DOP, even if coupled with vertical migrations, represents a recycling of organic matter rather than the input of new phosphorus into the upper euphotic zone.

In conclusion, although the formation of colonies in Trichodesmium has been seen mainly as an ecological adaptation for the protection of nitrogenase activity, our results support the notion that this morphological adaptation only enhances $\mathrm{N}_{2}$ fixation. If we consider that the velocity of vertical migration of a particle is proportional, not only to the difference of density with its surrounding medium, but to the square of its radius (i.e. Stoke's law; McCave 1984, Walsby 1992), the formation of colonies may be interpreted as a morphological adaptation to increase the frequency of vertical displacements of Trichodesmium in the water column. This suggestion is supported by the active uptake of inorganic phosphorus in the dark by sinking colonies and the accumulation of carbon under high light intensities. But, if Trichodesmium obtains its phosphorus for growth by active migration, then it is difficult to explain the high abundance of single trichomes in the water column of Stn ALOHA. One possible explanation comes from the observation by Ohki \& Fujita (1982) that, under certain conditions, single trichomes aggregate to form colonies. However, these authors observed de novo aggregations only when the density of trichomes was 2 orders of magnitude higher than the average density observed at Stn ALOHA. Furthermore, because DOP may also be considered a potential source of phosphorus for the single trichomes, the colonial morphology and the P-transport model may not represent a real advantage in terms of phosphorus uptake in the North Pacific subtropical gyre.

Finally, the carbohydrate ballast hypothesis, when considered in conjunction with the high critical tugor pressure of vacuoles observed in Trichodesmium spp. (Walsby 1992), suggests that intact filaments of these cyanobacteria are not significant contributors to the sinking flux of organic matter from the euphotic zone. If sinking Trichodesmium cells, unable to collapse their vacuoles, use carbohydrate ballast as an energy source, they will become positively buoyant under limiting conditions. Under this scenario, the only possibility for these cells to be exported permanently below the euphotic zone is by association with dense particles such as marine snow or discarded appendicularian houses (Alldredge 1976). Hence, we speculate that most elements incorporated into Trichodesmium biomass in the euphotic zone need to be recycled within the euphotic zone before being exported.

Acknowledgements. The authors thank the captains, crews and scientists participating in the HOT program for their assistance in the collection and analysis of the samples, P. K. Bienfang for lending his SETCOL columns, and 2 anonymous colleagues for their critical review of the manuscript. The present study was supported by National Foundation grants OCE88-00329, OCE90-16090 and OCE93-01368 (awarded to D.M.K.) and OCE87-17195 and OCE93-03094 (awarded to R. Lukas). SOEST publication \#4602 and U.S. JGOFS publication $\# 444$.

\section{LITERATURE CITED}

Alldredge AL (1976) Discarded appendicularian houses as a source of food, surface habitats and particulate organic matter in planktonic environments. Limnol Oceanogr 21 $14-23$

Armstrong FAJ, Williams PM, Strickland JDH (1966) Photooxidation of organic matter in sea water by ultraviolet radiation, analytical and other applications. Nature 211: $481-483$

Bergman B, Siddiqui PJA, Carpenter EJ, Peschek GA (1993) Cytochrome oxydase: subcellular distribution and relationship to nitrogenase expression in the nonheterocystous marine cyanobacterium Trichodesmium thiebautii. Appl Environ Microbiol 59:3239-3244

Bienfang PK (1981) SETCOL - a technologically simple and reliable method for measuring phytoplankton sinking rates. Can J Fish Aquat Sci 38:1289-1294

Bryceson I, Fay P (1981) Nitrogen fixation in Oscillatoria (Trichodesmium) erythraea in relation to bundle formation and trichome differentiation. Mar Biol 61:159-166

Capone DG, Carpenter EJ (1982) Nitrogen fixation in the marine environment. Science 217:1140-1142

Capone DG, O'Neil JM, Zher J, Carpenter EJ (1990) Basis for diel variation in nitrogenase activity in the marine planktonic cyanobacterium Trichodesmium thiebautis. Appl 
Environ Microbiol 56:3532-3536

Carpenter EJ (1973) Nitrogen fixation by Oscillatoria (Trichodesmium) thiebautii in the south-western Sargasso sea. Deep-Sea Res 20:285-288

Carpenter EJ (1983) Physiology and ecology of marine Oscillatona (Trichodesmium). Mar Biol Lett 4:69-85

Carpenter EJ, Capone DG (eds) (1983) Nitrogen in the marine environment, 1st edn. Academic Press, Boston

Carpenter EJ, Chang J, Cotrell M. Schubahuer J, Paerl H, Bebout BM, Capone DG (1990) Re-evaluatıon of nitrogenase-oxygen protective mechanisms in the planktonic marine cyanobacterium Trichodesmium. Mar Ecol Prog Ser 65:151-158

Carpenter EJ, McCarthy JJ (1975) Nitrogen fixation and uptake of combined nitrogenous nutrients by Oscillatoria (Trichodesmium) thiebautii in the western Sargasso sea. Limnol Oceanogr 20:389-401

Carpenter EJ, Price CC IV (1976) Marine Oscillatoria (Trichodesmium): explanation for aerobic nitrogen fixation without heterocysts. Science 191:1278-1280

Carpenter EJ, Price CC IV (1977) Nitrogen fixation distribution, and production of Oscillatoria (Trichodesmium) spp. in the western Sargasso and Caribbean seas. Limnol Oceanogr 22:60-72

Carpenter EJ, Romans K (1991) Major role of the cyanobacterium Trichodesmium in nutrient cycling in the North Atlantic Ocean. Science 254:1356-1358

Carpenter EJ, Scranton Ml, Novelli PC, Michaels A (1987) Validity of $\mathrm{N}_{2}$ fixation rate measurements in the marine Oscillatoria (Trichodesmium). J Plankton Res 9:1056-1087

Carpenter JH (1965) The Chesapeake Bay Institute technique for the Winkler dissolved oxygen method. Limnol Oceanogr 10:141-143

Chavez FP, Buck KR, Bidigare RR, Karl DM, Hebel D, Latasa M, Campbell L, Newton J (1995) On the chlorophyll a retention properties of glass fiber GF/F filters. Limnol Oceanogr 40:428-433

Codispoti LA (1989) Phosphorus vs. nitrogen limitation of new and export production. In: Berger WH, Smetacek VS, Wefer $G$ (eds) Productivity in the ocean: past and present. John Wiley \& Sons, New York, p 377-394

Cunningham K, Capone DG (1992) Superoxide dismutase as a protective enzyme against oxygen toxicity: an overview and initial studjes in Trichodesmium. In: Carpenter EJ, Capone DG, Reuter JG (eds) Marine pelagic cyanobacteria: Trichodesmium and other diazotrophs. Kluwer Academic Publishers, Boston, p 331-341

Devassy VP, Bhattathiri PMA., Quasim SZ (1978) Trichodesmium phenomenon. Ind J Mar Sci 7:168-186

DiTullio GR, Laws EA (1991) Impact of an atmosphericoceanic disturbance on phytoplankton community dynamics in the North Pacific Central Gyre. Deep-Sea Res 38: $1305-1329$

Donaghay PL, Liss PS, Duce RA, Kester DR, Hanson AK, Villareal T, Tindale NW, Gifford DJ (1991) The role of episodic atmospheric nutrient inputs in the chemical and biological dynamics of oceanic ecosystems. Oceanography $4: 62-70$

Doremus C (1982) Geochemical control of dinitrogen fixation in the open ocean. Biol Oceanogr 1:429-436

Duce RA, Liss PS, Merrill JT, Buad-Menard P, Hiccks BB, Miller JM, Prospero JM, Arimoto R, Church TM, Ellis W, Galloway JN, Hanson L, Jickells TD, Knapp AH, Reinhart $\mathrm{KH}$, Schneider B, Soudine A, Tokos JJ, Tsunogai S, Wollast $R$, Zhou $M$ (1991) The atmospheric input of trace species to the world ocean. Global Biogeochem Cycles 5: $193-259$
Dugdale RC, Goering JJ, Ryther JH (1964) High nitrogen fixation rates in the Sargasso sea and the Arabian sea. Limnol Oceanogr 9:507-510

Elardo K, Ammerman JW, Gundersen K (1994) Exoenzyme activity associated with Trichodesmium colonies. EOS 75: 111 (abstract)

Fogg GE (1982) Nitrogen cycling in sea waters. Phil Trans R Soc Lond B 269:511-520

Fogg GE (1987) Marine planktonic cyanobacteria. In: Fay P, Van Baalen C (eds) The Cyanobacteria. Elsevier, New York, p 394-4141

Ganf GG, Oliver RL (1982) Vertical separation of light and available nutrients as a factor causing replacement of green algae by blue-green algae in the plankton of a stratified lake. J Ecol 70:829-844

Goering JJ, Dugdale RC, Menzel DW (1966) Estimates of in situ rates of nitrogen fixation by Trichodesmium spp. in the Tropical Atlantic Ocean. Limnol Oceanogr 11:614-620

Howarth RW, Cole JJ (1985) Molybdenum availability, nitrogen limitation, and phytoplankton growth in natural waters. Science 229:653-655

Kamp AJ, Blanchard FA (1971) Quench correction in Cerenkov counting: channels ratio and external source channels ratio methods. Analyt Biochem 44:369-380

Kana TM (1992) Oxygen cycling in cyanobacteria with specific reference to oxygen protection in Trichodesmium spp. In: Carpenter EJ, Capone DG, Reuter JG (eds) Marine pelagic cyanobacteria: Trichodesmium and other diazotrophs. Kluwer Academic Publishers, Boston, p 29-41

Karl DM, Christian JR, Dore JE, Hebel DV, Letelier RM, Tupas LM, Winn CD (1996) Seasonal and interannual variability in primary production and particle flux at Station ALOHA. Deep-Sea Res (Part II) 43:539-568

Karl DM, Letelier R, Hebel DV, Bird DF, Winn CD (1992) Trichodesmium blooms and new nitrogen in the North Pacific gyre. In: Carpenter EJ, Capone DG, Reuter JG (eds) Marine pelagic cyanobacteria: Trichodesmium and other diazotrophs. Kluwer Academic Publishers, Boston. p 219-237

Karl DM, Letelier R, Tupas L, Dore J, Christian J, Hebel D (1997) The role of nitrogen fixation in biogeochemical cycling in the subtropical North Pacific Ocean. Nature $388.533-538$

Karl DM, Letelier R, Hebel D, Tupas L, Dore J, Christian J, Winn C (1995) Ecosystem changes in the North Pacific subtropical gyre attributed to the 1991-92 El Niño. Nature $373: 230-234$

Karl DM, Tien G (1997) Temporal variability in dissolved phosphorus concentrations at Station A.LOHA $\left(22^{\circ} 45^{\prime} \mathrm{N}\right.$, $\left.158^{\circ} \mathrm{W}\right)$. Mar Chem 56:77-97

King FD (1986) The dependence of prmary production in the mixed layer of the eastern tropical Pacific on the vertical transport of nitrate. Deep-Sea Res 33:733-754

Klemer AR, Feuillade J, Feuillade M (1982) Cyanobacterial blooms: carbon and nitrogen limitation have opposite effects on the buoyancy of Oscillatoria. Science 215: $1629-1631$

Konopka AE (1984) Effect of light-nutrient interactions upon the physiological state of planktonic cyanobacteria. In: King MI, Reddy $C$ (eds) Current perspectives in microbial ecology. Am Soc Microbiol, Washington, DC, p 41-48

Kromkamp JC, Mur LR (1984) Buoyant density changes in the cyanobacterium Microcystis aeruginosa due to changes in the cellular carbohydrate content. FEMS Microbiol Lett 25:105-109

Letelier RM (1994) Studies on the ecology of Trichodesmium spp. (Cyanophyceae) in the Central North Pacific gyre. PhD thesis, University of Hawaii, Honolulu 
Letelier RM, Dore JE, Winn CD, Karl DM (1996) Seasonal and interannual variations in photosynthetic carbon assimilation at Sta. ALOHA. Deep-Sea Res (Part II) 43:467-490

Letelier RM, Karl DM (1996) Role of Trichodesmium spp. in the productivity of the subtropical North Pacific Ocean. Mar Ecol Prog Ser 133:263-273

Lewis MR, Harrison WG, Oakey NS, Hebert D, Platt T (1986) Vertical nitrate fluxes in the oligotrophic ocean. Science 234:870-873

Lewis MR, Ulloa O, Platt T (1988) Photosynthetic action, absorption and quantum yield spectra for a natural population of Oscillatoria in the North Atlantic. Limnol Oceanogr 33:92-98

Li WKW, Glover HE, Morris I (1980) Physiology of carbon assimilation by Oscillatoria thiebautii in the Caribbean Sea. Limnol Oceanogr 25:447--456

Mague TH, Mague FC, Holm-Hansen O (1977) Physiology and chemical composition of nitrogen fixing phytoplankton in the central North Pacific Ocean. Mar Biol 41: 213-227

Mague TH, Weare MM, Holm-Hansen O (1974) Nitrogen fixation in the North Pacific Ocean. Mar Biol 24:109-119

Marino R, Howarth RW, Shamess J, Prepas E (1990) Molybdenum and sulfate as controls an the abundance of nitrogen fixing cyanobacteria in saline lakes in Alberta. Limnol Oceanogr 35:245-259

Martin JH, Fitzwater SE (1988) Iron deficiency limits phytoplankton growth in the North-east Pacific subarctic. Nature 331:341-343

Marumo R, Asaoka O (1974) Distribution of pelagic bluegreen algae in the North Pacific Ocean. J Oceanogr Soc Jpn 30:77-89

McCarthy JJ, Carpenter EJ (1979) Oscillatoria (Trichodesmium) thiebautii (Cyanophyta) in the Central North Atlantic Ocean. J Phycol 15:75-82

McCave IN (1984) Size spectra and aggregation of suspended particles in deep ocean. Deep-Sea Res 31:329-337

Morel FMM, Reuter JC, Anderson DM, Guillard RRL (1979) Aquil: a chemically defined phytoplankton culture medium for trace metal studies. J Phycol 15:135-141

Murphy J, Riley JP (1962) A modified single solution method for determination of phosphate in natural waters. Analyt Chim Acta 27:31-36

Ohki K, Fujita Y (1982) Laboratory culture of the pelagic bluegreen algae Trichodesmium thiebautii: conditions for unialgal culture. Mar Ecol Prog Ser 7:185-190

Ohki K, Fujita Y (1988) Aerobic nitrogenase activity measured as acetylene reduction in the marine non-heterocystous cyanobacterium Trichodesmium spp. grown under artificial conditions. Mar Biol 98:111-114

Paerl HW, Bebout BM (1988) Direct measurement of $\mathrm{O}_{2}$ depleted microzones in marine Oscillatoria: relation to $\mathrm{N}_{2}$ fixation. Science 241:442-445

Paerl HW, Bebout BM, Prufert LE (1989) Bacterial associations with marine Oscillatoria sp. (Trichodesmium sp.) populations: ecophysiological implications. J Phycol 25: $773-784$

Paerl HW, Bland PT (1982) Localized tetrazolium reduction in relation to $\mathrm{N}_{2}$ fixation, $\mathrm{CO}_{2}$ fixation, and $\mathrm{H}_{2}$ uptake in aquatic filamentous cyanobacteria. Appl Environ Microbiol 56:218-226

Paerl HW, Prufert LE (1987) Oxygen-poor microzones as potential sites for microbial $\mathrm{N}_{2}$ fixation in nitrogen depleted marine waters. Appl Environ Microbiol 53: 1078-1087

Platt T, Harrison WG, Lewis MR, Li WKW, Sathyendranath $S$, Smith RE, Vezina A (1989) Biological production of the oceans: the case for a consensus. Mar Ecol Prog Ser 52: $77-88$

Prufert-Bebout L, Paerl HW, Lassen C (1993) Growth, nitrogen fixation, and spectral attenuation in cultivated Trichodesmium species. Appl Environ Microbiol 59: $1367-1375$

Redfield AC, Ketchum BH, Richards FA (1963) The influence of organisms on the composition of seawater. In: Hill $M N$ (ed) The sea: ideas and observations on progress in the study of the seas, Vol 2. Interscience, New York, p 26-77

Reuter JG (1982) Theoretical Fe limitations of microbial $\mathrm{N}_{2}$ fixation in oceans. EOS 63:945 (abstract)

Reuter JG (1988) Iron stimulation of photosynthesis and nitrogen fixation in Anabaena 7120 and Trichodesmium (Cyanophyceae). J Phycol 24:249-254

Romans KM, Carpenter EJ, Bergman B (1994) Buoyancy regulation in the colonial diazotrophic cyanobacterium Trichodesmium tenue: ultrastructure and storage of carbohydrate, polyphosphate, and nitrogen. J Phycol 30:935-942

Saino T, Hattori A (1978) Diel variation in the nitrogen fixation by marine blue-green alga, Trichodesmium thiebautii. Deep-Sea Res 25:1259-1265

Saino T, Hattori A (1980) Nitrogen fixation by Trichodesmium and its significance in nitrogen cycling in the Kuroshio area and adjacent waters. In: Takenouti AY (ed) The Kuroshio IV. Saikon Publishing Company, Tokyo, p 697-709

Saino T, Hattori A (1982) Aerobic nitrogen fixation by the marine non-heterocystous cyanobacteria Trichodesmium (Oscillatoria) spp.: its protective mechanism against oxygen. Mar Biol 70:251-254

Scranton MI, Novelli PC, Michaels A, Horrigan SG, Carpenter EJ (1987) Hydrogen production and nitrogen fixation by Oscillatoria thiebautii during in situ incubations. Limnol Oceanogr 32:998-1006

Taylor BF, Lee CC, Bunt JS (1973) Nitrogen fixation associated with the marine blue-green alga, Trichodesmium as measured by the acetylene reduction technique. Arch Mikrobiol 88:205-212

Villareal TA, Altabet MA, Culver-Rymsza K (1993) Nitrogen transport by vertically migrating diatom mats in the North Pacific Ocean. Nature 363:709-712

Villareal TA, Carpenter EJ (1990) Diel buoyancy regulation in the marine diazotrophic cyanobacterium Trichodesmium thiebautii. Limnol Oceanogr 35:1832-1837

Wada E, Hattori A (eds) (1991) Nitrogen in the sea: forms, abundances, and rate processes. CRC Press, Boca Raton

Walsby AE (1978) The properties and buoyancy-providing role of gas-vacuoles in Trichodesmium Ehrenberg. Br Phycol J 13:103-116

Walsby AE (1992) The gas vesicules and buoyancy of Trichodesmum. In: Carpenter EJ, Capone DG, Reuter JG (eds) Marine pelagic cyanobacteria: Trichodesmium and other diazotrophs. Kluwer Academic Publishers, Boston, p $141-161$

Yentsch CM, Yentsch CS (1972) Alkaline phosphatase activity in the tropical marine blue-green alga, Oscillatoria erythraea ('Trichodesmium'). Limnol Oceanogr 17:772-774

Submitted: June 10, 1997; Accepted: March 3, 1998

Proofs received from author(s): July 18, 1998 